\title{
Cognitive Retroactive Transfer (CRT) of Language Skills among Trilingual Arabic-Hebrew and English Learners
}

\author{
Salim Abu-Rabia, Wael Shakkour \\ Faculty of Education, University of Haifa, Haifa, Israel \\ Email: Salimar@construct.haifa.ac.il
}

Received 5 November 2013; revised 8 December 2013; accepted 15 December 2013

Copyright (C 2014 by authors and Scientific Research Publishing Inc.

This work is licensed under the Creative Commons Attribution International License (CC BY). http://creativecommons.org/licenses/by/4.0/ (c) (i) Open Access

\begin{abstract}
This study examined whether helping poor readers improve their reading and writing language skills in English as a third language/foreign language (L3/FL) would also bring about an improvement in those same skills in Arabic (L1) and Hebrew (L2). Transferring linguistic skills from L3/FL to both L1 and L2 is termed "Cognitive Retroactive Transfer" (CRT). A battery of tests, administered to the experiment and control groups, assessed orthographic knowledge, phonological awareness, morphological awareness, syntactic awareness, reading accuracy and reading comprehension in English, Arabic, and Hebrew. The treatment group was provided with an intervention program in English, but not in Arabic or Hebrew, both before and after the experiment. Findings indicated a significant improvement in the treatment group's achievements in all linguistic and meta-linguistic skills in all study languages after the intervention, except for orthographic knowledge in Arabic and Hebrew. The results are discussed in light of the international data.
\end{abstract}

\section{Keywords}

English as a Third Language/Foreign Language; Arabic as a First Language; Hebrew as a Second Language; Cognitive Retroactive Transfer (CRT) Hypothesis; Metacognitive Skills; Modular Process

\section{Introduction}

Israel is a pluralistic, highly functional, multicultural, multilingual, and multi-religious society. This reality requires that Israeli Arabs-the country's largest ethnic minority-learn three languages: Arabic, Hebrew, and English. Arab children speak Arabic as their mother tongue/first language (L1) and are schooled in it. They formally begin studying the Arabic language in the first grade. But they must also learn the country's main official 
language, Hebrew, and are highly motivated to do so, since they will need the language for every aspect of daily life, from simply being able to read commercial and government mail to accessing higher education. Arab children study Hebrew as their second language (L2) from the $3^{\text {rd }}$ grade. Finally, they must also be educated in English, both as a required school discipline and because of its international status in every field all over the world, including academia, economics, and politics. English is taught in Arab schools as a third language (L3/FL) from the $4^{\text {th }}$ grade.

It is a commonly held assumption that it is easier for good readers to acquire additional languages, while the opposite is assumed for poor ones (Geva, Yaghoub-Zadeh, \& Schuster, 2000). According to Abu-Rabia and Siegel (2002), children who perform poorly in their mother tongue will also exhibit weakness in L2 and L3, while children whose performance is high in their mother tongue will attain similar results in other languages as well. The explanation offered for either the success or difficulty of acquiring L2 and L3 is that the same metalinguistic skills connected with reading and writing, like phonological awareness, orthographic awareness, morphological awareness and more, are common to all languages.

Therefore, if linguistic skills in one language are found to be well developed, the same level will be reflected in another language (Cummins, 1979, 1981). Similarly, should linguistic skills in one language be deficient, so will they be in another language (Geva, 1995). This explanation corresponds to Cummins's Linguistic Interdependence Hypothesis $(1979,1981)$. The obvious question then, is whether such a transfer can occur in the opposite direction. That is to say, is there a transfer of linguistic and meta-linguistic skills from L3 to L1 and to L2? In other words, is there cognitive retroactive transfer (CRT) of skills? If we can prove that such a transfer of skills indeed occurs from L3 to both L1 and L2, then this will constitute the innovation of this study.

\section{Arabic Orthography}

Arabic is a language read from right to left and written in an alphabetic system of 28 letters, all consonants, three of them also serving as long vowels (Abu-Rabia, 2001b; Abu-Rabia \& Saliba, 2008). There are many similarities between the letters, which are divided into categories according to basic shape, while the differences between them lie in the number of dots that appear, as a feature of the script, over, within, or under the letters (Abu-Rabia, 1998, 2001b; Azzam, 1989). In addition, because the Arabic script is fundamentally cursive, most letters have slightly different forms depending on whether they occur at the beginning, middle, or end of the word. However, the essential shape of the letter is maintained in all cases (Abd El-Minem, 1987). The Arabic writing system carries some ambiguity, because short vowels are not represented by letters. Instead, they are represented by diacritical marks - short vowel signs above, and/or within, and/or below, letters-in order to attain proper letter-sound pronunciation. Thus, Arabic words are a combination of consonants and vowels (both short and long) (Abu-Rabia \& Saliba, 2008; Abd El-Minem, 1987). Voweled, or vocalized, Arabic script can be described as shallow orthography for beginning readers, and non-vocalized Arab script as deep orthography for more advanced readers (Abu-Rabia, 2001b, 2002; Abu-Rabia \& Siegel, 2003). Arabic morphology is based on roots and word patterns: the root conveys semantics, and the word pattern conveys morpho-syntactic and phonological information. In this respect, Arabic resembles Hebrew. Arabic roots contain three or four letters, with some being formed by either two or five consonants (Abu-Rabia, 2001b). The root morpheme represents the basic semantic entity of the general word, but is not a phonological unit, so pronunciation may not be clearly defined (Abu-Rabia, 2007; Abu-Rabia \& Taha, 2006; Frost et al., 1997). Arabic morphology is constructed from two types of structures: derivational and inflectional (Abu-Rabia, 2001b, 2002). Arabic derivational morphology produces words based on the root consonants and affixed word pattern. The word pattern can be built of prefixes, suffixes, and infixes, causing changes in phonemic structure as well as the orthographic structure of the basic root morpheme. This causes difficulties in reconstructing the words going back to the root from which they were derived (Abu-Rabia \& Taha, 2006; Saiegh-Haddad \& Geva, 2008). The complexity of Arabic morphology makes it opaque, making the development process of Arab children's linguistic awareness rather difficult (AbuRabia, 2002; Saiegh-Haddad \& Geva, 2008). In contrast, the inflectional morphological system in Arabic is constructed by attaching prefixes and suffixes to real words. The system of inflectional morphology of verbs is systematic, and takes into consideration verb-form (person), number, gender, and tense (Abu-Rabia, 2001b; Abu-Rabia \& Saliba, 2008; Abu-Rabia \& Siegel, 2003). Some scholars have considered Arabic as a case of diglossia, a term according to which the spoken and the written language are substantially different from one another in terms of vocabulary, phonology, syntax, and grammar. This means that children in a diglossic situa- 
tion have to cope with reading and writing in a language with which they are unfamiliar (Abu-Rabia, 2001b; Saiegh-Haddad, 2005).

\section{Hebrew Orthography}

Hebrew shares certain similarities with Arabic: It is considered a Semitic language, it is written in an alphabetic system, it is a system of consonants, and it is read and written from right to left (Shimron, 1993). Hebrew orthography consists of 22 letters, five having different forms when they appear at the end of the word. Vocalized Hebrew should be considered a shallow orthography, characterized by short vowels of dots and dashes (diacritical marks) placed below, above, or within the consonants. Furthermore, vocalized Hebrew is characterized by a direct and almost universal correspondence between graphemes and phonemes, which enables beginning readers to learn accurate decoding (Ravid, 2003; Shimron \& Sivan, 1994). The non-vocalized script is a deep orthography, containing a limited amount of vowel information, but a large number of homographs. In such a situation, words can be decoded in several ways. In such cases, the reader relies on context or linguistic knowledge to accurately decode the words (Kahn-Horwitz, Shimron, \& Sparks, 2005; Katz \& Frost, 1992; Shimron, 1993). Skilled and adult readers read Hebrew script without diacritics. Hebrew morphology, like other Semitic languages, is constructed from a root and a word pattern. The root contributes semantic and morphological information, while the word pattern categorizes the function of the word (Ravid, 2003). The root is a discontinuous morpheme that consists of three or four consonants, whereas word patterns can be either a sequence of vowels, or a sequence of both vowels and consonants. Roots and word patterns are abstract structures because only their joint combination results in specific phonemic word forms with specific meanings (Katz \& Frost, 1992; Shimron, 1993). Root and vowel combinations may produce several different words that carry different meanings. In addition, adding affixes (prefixes and suffixes), and syllables to the root indicates gender, number, verb-form (person,) and tense. This helps the reader pronounce words accurately, and understand the syntax and grammatical role of the word in the sentence (Katz \& Frost, 1992; Schwarzwald, 2001; Shimron \& Sivan, 1994).

\section{Transfer of Proficiency: Hypotheses and Data}

The purpose of this study is to examine the CRT of linguistic skills from L3 English to two other languages: L1 Arabic and L2 Hebrew. This is an extension of Abu-Rabia and Blueistin-Danon (2012), and Abu-Rabia, Shakkour and Siegel's (2013) studies where the CRT was tested among bilingual Hebrew-English poor. However in the present study, the CRT was tested among trilingual Arabic-Hebrew-English learners in an attempt to test the transferability of language skills from English as a FL/L3 to both Arabic as their L1 and Hebrew as their L2 of the learners.

Research studies that examined transfer of linguistic skills between languages focused mainly on two basic hypotheses: the interdependence hypothesis (IH), which proposes that Cognitive Academic Language Proficiency (CALP) is transferred from one language to another, and the Script Dependent Hypothesis (SDH), which suggests that first language reading efficiency does not necessarily influence reading abilities in a second language (Liberman, Shankweiler, Fischer, \& Carter, 1974; Lindgren, Dernzi, \& Richman, 1985).

\subsection{The Interdependence Hypothesis (IH)}

Cummins $(1979,1981)$ argues that a significant relationship exists between L1 and L2, so a deficiency in one language will also be exhibited in the other. In addition, reading and writing proficiency and general academic skills that are successfully acquired in the first language should ostensibly be transferred to the second automatically. The main idea of this hypothesis is that learning two languages will improve the learning process of both, regardless of the orthography type (Cummins, 1979). This hypothesis is based on the assumption that the basic cognitive academic knowledge proficiency common to all languages allows the transfer of linguistic skills from one language to another (Cummins, 1979, 1981).

\subsection{The Script Dependent Hypothesis (SDH)}

This hypothesis suggests that reading efficiency in L2 is a direct function of L1 orthography, and that orthographic differences play an important role in the L2 reading process. The hypothesis also argues that reading development in a certain language will be constrained by the orthographic features of that language. The SDH 
proposes that reading problems in one language will reflect the degree of grapheme-phoneme correspondence in that language, and that this will not influence another language. Thus, children's reading efficiency in a particular language does not necessarily influence their ability to read a second language. Furthermore, each language develops independently from another. The main focus of this hypothesis is consideration of the characteristics of the L1 orthography during the reading acquisition process of the different orthographies of the L2 (Liberman et al., 1974; Lindgrenet al., 1985).

\subsection{Predictors of Reading Acquisition}

Learning to read is essentially the art of mapping between the spoken and printed/written form of the language (Adams, 1990; Perfetti, 1985, 2003). It is a process of interpreting and understanding written language that begins with visual stimulation and ends with an understanding of the idea the writer is trying to convey (Rayner \& Pollatsek, 1989). According to Perfetti $(1985,2003)$, learning to read symbolizes the deciphering of the spoken language as expressed in a written framework. The reading process is reflected only by the ability to understand the meaning of the text, while the process itself is a very comprehensive one, and includes evaluating, identifying, interpreting, and understanding the deep stratum of the text. Therefore, learning to read involves and demands a complex cognitive process, which in itself requires mastery of several linguistic and meta-linguistic skills (Adams, 1990; Ziegler \& Goswami, 2005). The following is a short literary review of the linguistic and meta-linguistic skills referred to in the present study.

\section{Transfer of Cross-Language Skills}

\subsection{Phonological Awareness}

Phonological awareness is a linguistic skill that relates to the ability to identify and manipulate sounds of speech that include spoken words, syllables, onsets, rhymes, and phonemes (Ehri, 1997; Gillon, 2002; Goswami \& Bryant, 1990; Mann, 1998; Stanovich, 1986). Good phonological awareness is a crucial skill for decoding connections between phonemes and sounds of letters, an ability which not only leads to spelling and reading fluency, but also serves as a significant and reliable predictor of later reading abilities (Lipka, Siegel, \& Vukovic, 2005; Chiappe, Siegal, \& Gottardo, 2002). Even though phonological awareness itself is not a reading skill but more a language skill, it is strongly related to the development of reading proficiency (Geva \& Siegel, 2000; Lipka, et al., 2005; Lyon, Fletcher, \& Barnes, 2003). It is probably best described as an Linguistic cognitive skill that can be transferred between languages, and which can serve as a key predictor of reading abilities not only in the mother tongue, but for L2 and L3 as well (Adams, 1990; Ball, 1993; Chiang \& Rvachew, 2007; De Jong \& Van der Leij, 1999; Durgunoglu \& Ony, 1999; Laurent \& Martiont, 2010; Mann, 1998; Sun-Alperin \& Wang, 2009; Al-Tamimi \& Rabab'ah, 2007). Many studies have examined the transfer of phonological skills between Arabic (with transparent orthography when vocalized) and English (with opaque orthography) (Abu-Rabia \& Siegel, 2002, 2003; Al-Tamimi \& Rabab’ah, 2007; Saiegh-Haddad \& Geva, 2008). In these studies, the researchers reported the transfer of phonological skills between Arabic and English, and also found significant correlation between phonological awareness in Arabic, and reading acquisition in English. Wade-Woolley and Geva (2000) have examined linguistic transfer of phonological awareness between English and Hebrew (defined as a shallow orthography) among bilingual children learning to read in both languages. This finding indicated important relationships between phonological systems of languages. In addition, phonological awareness was a good predictor of reading acquisition in both languages. Based on these finding, the researchers suggest that the concept of the alphabetic language, together with a number of phonological principles unrelated to a specific language, can be transferred from one language to another. Similar findings were found in Spanish (shallow orthography) and English (Bialystok, Luk, \& Kwan, 2005; Cisero \& Royer, 1995; Durgunoglu, Nagy, \& Hancin-Bhatt, 1993; Sun-Alperin \& Wang, 2009). Sun-Alperin and Wang (2009) revealed that accuracy on a phoneme deletion task in Spanish contributed to the correct reading and spelling of words and pseudo-words in both Spanish L1 and English L2. Identical findings were revealed between Korean, considered an alphabetic language, and English (Chiappe, Glaeser, \& Ferko, 2007; Kim, 2009; McBride-Chang et al., 2005; Wang, Cheng, \& Chen, 2006). Kim (2009) found that identifying rhymes in Korean L1 correlated with phonological awareness in English L2. In addition, phonological skills in Korean positively contributed to the decoding of words in English, in spite of the difference in phonological representation between the two languages. Similar findings were revealed regarding 
phonological awareness transfer between German and English (Mann \& Wimmer, 2002), Farsi and English (Arab-Moghaddam \& Sénéchal, 2001), French and English (Chiang \& Rvachew, 2007), Italian and English (D’angiulli, Siegel, \& Serra, 2001), Portuguese and English (da Fontoura \& Siegel, 1995), Russian and English (Abu-Rabia \& Sanitsky, 2010), and Chinese and English (McBride-Chang et al., 2008). The findings of all of these studies support Cummins's IH (1979, 1981).

\subsection{Orthographic Knowledge}

Orthographic knowledge refers to the written framework of any given language, and consists of the orthographic symbols used in the written word that help in its identification and proper understanding (Ehri, 1992; Nassaji \& Geva, 1999), whether an isolated word or within full texts (Wagner \& Barker, 1994). Knowledge of the names of the letters of any alphabet constitutes one of the most fundamental indicators of the proper acquisition of reading skills among beginners (Badian, 1995; Scanlon \& Vellution, 1997; Snow, Burns, \& Griffin, 1998). Since such basic knowledge of names of letters also often describes their sounds, it allows beginning readers to acquire their first word-decoding strategies (Carroll, 2000). To acquire L2 orthographic skills, learners need to develop sensitivity towards orthographic rules in the target language. That means that learners of any language must understand the heterogeneous nature of orthographic information; specifically, they must know written symbols, recognize accepted patterns, and understand linguistic rules, as well as master the correspondence of symbols and their sounds (Shiotsu, 2009). Numerous studies have examined cross-language transfer of orthographic skills: (Abu-Rabia, 2001a; Abu-Rabia \& Sanitsky, 2010; Abu-Rabia \& Siegel, 2002, 2003; Arab-Moghaddam \& Sénéchal, 2001; Deacon, Wade-Woolley, \& Kirby, 2009; Kahn-Horwitz et al., 2005; Nassaji \& Geva, 1999; Ryan \& Meara, 1991; Sun-Alperin \& Wang, 2009; Wang, Park, \& Lee, 2006). However, no consensus can be indicated from the findings of these studies on whether orthographic knowledge is transferred between languages, or even whether or not it is language-specific (script-dependent). Abu-Rabia and Sanitsky (2010) indicated that orthographical skills in Russian L1 and in Hebrew L2 were a good predictor of orthographic proficiencies, reading and spelling in English L3. The researchers explained their findings by suggesting that the study of two orthographies enriches the child's orthographic lexicon and helps him to acquire a third orthography, despite the difference in depth of the last orthography from the other two. Leikin, Share, and Schwartz (2005) examined the transfer of linguistic skills between two shallow orthographies, Hebrew and Russian. The findings indicated that orthographic skills in Russian were a strong predictor of reading and spelling abilities in Hebrew L2. Deacon and colleagues (2009) examined the transfer of orthographic skills between two languages with deep orthography, English and French. Their findings revealed important correlations between the orthographic systems of both languages, and found a strong positive correlation between processing orthography in English and proper reading and spelling in French. The researchers explained their findings by claiming that the higher the level of similarity between two orthographies, the greater the chance of a linguistic transfer of orthographic knowledge. That is to say, both languages are alphabet-based, both orthographies are considered deep and both use Latin characters. Similar results were obtained between Arabic and English (Abu-Rabia \& Siegel, 2002), Hebrew and English (Kahn-Horwitz et al., 2005), Persian and English (Nassagi \& Geva, 1999), and Chinese and English (Wang, Koda, \& Perfetti, 2003). These previous studies' findings indicated that neither orthographic knowledge nor the transfer of skills between languages is language-specific. Also, these studies support Cummins's IH (1979, 1981). In contrast, there are many studies that investigated languages that differ in orthographic character (shallow and deep orthographies, alphabetical and logographical orthographies), indicated that orthographic knowledge is language-specific and cannot transfer between languages (Abu-Rabia, 1997a, 2001a; Abu-Rabia \& Siegel, 2003; Arab-Moghaddam \& Sénéchal, 2001; Morfidi, Van der Leij, de Jong, Scheltinga, \& Bekebrede, 2007; Ryan \& Meara, 1991; Sun-Alperin \& Wang, 2009; Wang et al., 2006). These findings are consistent with the SDH (Liberman et al., 1974; Lindgren et al., 1985). Abu-Rabia (1997a) examined Hebrew bilingual students studying English L2. His findings indicate that syntax skills, working memory and reading proficiencies of L1 tend to be transferred to L2, except for orthographic skills, which are language-specific. Ryan and Mera (1991) examined Arabic-speaking children learning English L2. Their findings revealed that native adult Arabic readers read texts without short vowels, which is a strategy they transferred from Arabic to the English script. This means that different orthographies lead to different types of errors in L2 learning, implying that orthographic knowledge is not transferred between languages and is indeed language-specific. Sun-Alperin \& Wang (2009) indicated that processing orthography did predict reading and spelling abilities in the languages 
Spanish L1and English L2, but there was no transfer between them. In other words, orthographic patterns may be language-specific, and therefore unlikely to transfer to the other language. Identical findings were shown between Circassian and English (Abu-Rabia, 1997b), Dutch and English (Morfidi et al., 2007), Persian and English (Arab-Moghaddam \& Sénéchal, 2001), Korean and English (Wang, Ko, \& Choi, 2009), Russian and English (Abu-Rabia, 2001a), and Chinese and English (Keung \& Ho, 2009).

\subsection{Morphological Awareness}

Morphological awareness means being aware of a word's morphological structure and being able to manage that structure (Carlisle, 1995; Carlisle \& Stone, 2003). This includes a child's ability to apply morphemic knowledge when identifying and creating more morphologically complex forms of words, and in adapting the new structure to the given language. Morphology is the component of language that deals with the study of word form. Morphological awareness, or the awareness of morphemes (the smallest units of meaning in a language), has been the most extensively researched aspect of morphology (Perfetti, 1985; Byrne, 1996). Many studies that examined the early stages of reading acquisition have suggested that young children show a fundamental understanding of morphological word components. Byrne (1996) noted that English-speaking children in the early reading stage tended to notice the morphological features more than the phonological characteristics of new words, and that morphological awareness of the spoken language contributed to the child's reading development (Deacon \& Kirby, 2004; Mahony, Singson, \& Mann, 2000). Few studies examined morphological cross-language transfer, but these indicated that morphological features influence the transfer direction of morphological skills. Transparent orthographies usually have a deep and complex morphological system, whereas deep orthographies have a transparent and simple morphological system. Consequently, it should be easier to transfer morphological skills from deep morphological systems like Arabic, Hebrew, Spanish, Finnish and Korean to transparent morphological systems, like English, but not vice versa (Bindman, 2004; Jarvis \& Odlin, 2000; Ramirez, Chen, Geva, \& Kiefer, 2010; Saiegh-Haddad \& Geva, 2008; Wang et al., 2009). These studies examined the relationship between morphological skills and reading acquisition among native bilingual individuals from various language backgrounds (defined as shallow orthographies), when learning English L2. The findings indicated that morphological awareness predicts reading measures within the L1 and L2; native languages' morphological awareness significantly contributed to reading skills in English L2, but not vice versa. In other words, the findings revealed unidirectional morphological awareness cross-language transfer, from shallow orthographies with deep morphological systems to deep orthographies with shallow morphological systems, but not the other way around.

In summary, studies that revealed cross-language transfer of morphological skills support Cummins's IH $(1979,1981)$, while findings of non-transfer of morphological awareness from English to other languages with shallow orthographies support the SDH (Liberman et al., 1974; Lindgren et al., 1985).

\subsection{Syntactic Awareness}

Syntactic awareness is necessary for helping the reader understand the role of each word in a sentence, and is also helpful in understanding the meaning of full sentences and the context of concepts within sentences (Just \& Carpenter, 1987). Durgunoglu (2002) claimed that to have a command of syntactic awareness, one must see things in meta-linguistic terms, which relate to the ability to discern the internal grammatical structure of sentences in a language. As such, syntactic awareness is a very important contributor, providing an understanding of how to combine words into larger syntactical units, like sentences and paragraphs (Alderson, 1993; Just \& Carpenter, 1987; Rayner \& Pollatsek, 1994). Abu-Rabia and Siegel (2002, 2003) found a positive correlation in syntax skills between Arabic L1 and English L2/L3. Furthermore, syntactic awareness in Arabic predicted proper identification and reading of English words and pseudo-words. Similar findings were found between Hebrew and English (Abu-Rabia, 1997a; Geva \& Siegel, 1991, 2000). Geva and Siegel (2000) examined cognitive and orthographic factors in two languages, Hebrew and English. They indicated a strong correlation in syntactic awareness between Hebrew L1 and English L2. The researchers concluded that transfer of syntactic skills from L1 to L2 occurred regardless of the type of orthography. Identical findings were obtained between Spanish and English (Durgunoglu, Mir, \& Arino-Martl, 2002; Dussias \& Scaltz, 2008; Galambos \& Goldin-Meadow, 1990). Durgunoglu and colleagues (2002) found a significant correlation of syntactic awareness between Spanish L1 and English L2. Children who accurately analyzed and corrected the syntactic structure of a sentence in one 
language showed a much higher probability of accomplishing the same in the other language. This certainly indicates that meta-linguistic awareness is common to both languages. Similar results were obtained in studies which examined syntactic awareness transfer between Russian and English (Abu-Rabia \& Sanitsky, 2010), Swedish and English (Cromdal, 1999) and Italian and English (D'angiulli et al., 2001). The earlier research findings demonstrated that cross-language transfer of syntax skills supports the Cummins's IH $(1979,1981)$. In contrast, numerous studies that examined cross-language transfer of syntactic awareness skills among bilingual individuals from diverse language backgrounds, like Portuguese, Cantonese, Mandarin, Gujarati, Urdu, and L2 English, have shown that bilinguals' performance of L1 syntactic awareness tasks did not predict similar results in L2 English (Cheung, Chan, \& Chong, 2007; Chiappe \& Siegel, 1999; Chiappe, Siegel, \& Wade-Woolley, 2002; da Fontoura \& Siegel, 1995; Davidson, Raschke, \& Pervez, 2010; Gottardo, Siegel, \& Wade-Woolley, 2001; Lesaux \& Siegel, 2003; Wade-Woolley \& Siegel, 1997). Davidson and colleagues (2010) conducted a study involving reading and syntactic awareness tasks among bilingual Korean children studying English L2. The findings indicated that the Korean children's achievements in syntactic awareness tasks in English L2 were low compared to their performance in Korean L1. This means that Korean syntactic awareness skills were not transferred to the English L2. Similarly, Gottardo and colleagues (2001) reported that there was no definitive evidence of syntactic skill transfer from Chinese L1 to English L2. Previous findings have demonstrated that syntactic awareness skills are language-specific, supporting the SDH (Liberman et al., 1974; Lindgren et al., 1985).

\subsection{Reading Comprehension}

Reading comprehension refers to the correct understanding of the written or oral word or message, and is achieved when the reader successfully condenses information and combines various details of the text with prior knowledge (Koda, 2007). According to Snow and Sweet (2003), reading comprehension is a multi-dimensional and complex process that requires high cognitive ability of extraction and construction, in that the reader extracts the meanings from the text, while at the same time combining them with existing knowledge in order to construct new meanings. This suggests that the interaction between a text and a child's basic knowledge will contribute to reading comprehension development (Alderson \& Urguhart, 1988). Numerous research study findings indicate that linguistic components of L1, such as phonological awareness, morphological awareness, orthographic knowledge, syntactic awareness, vocabulary and meta-cognitive knowledge, all contribute to reading comprehension development in a second language (Lefranc \& Armand, 2003; Kahn-Horwitz et al., 2005; Kieffer \& Lesaux, 2008; Nassaji \& Geva, 1999; Proctor et al., 2006; Van der Leij, Bekebrede, \& Kotterink, 2010; Wang et al., 2009; Zhang \& Koda, 2008). Kahn-Horwitz and colleagues (2005) found that linguistic skills of phonological awareness, morphological awareness, and word-recognition in Hebrew L1 were a significant predictor of reading comprehension in English L2. Lefranc and Armand (2003) indicated that syntax knowledge in Spanish L1 significantly contributed to reading comprehension acquisition in French L2. Identically, Van der Leij and colleagues (2010) found that Dutch bilingual children's reading comprehension skills in their primary tongue, Dutch, were better than those of Dutch monolingual children, suggesting that exposure to an additional language can improve reading skills in the primary language. Zhang and Koda (2008) revealed that morphological awareness in both languages, Chinese L1 and English L2, was a strong predictor of reading comprehension in English L2. The conclusions of previous studies support Cummins's IH (1979, 1981). In contrast, other studies' findings have shown that there is no cross-language transfer of skills that can contribute to L2 reading comprehension skill development (Akamatsu, 2003; Garcia, 1991; Guo \& Roehrig, 2011; Shimron \& Sivan, 1994; Verhoeven, 2000; Wang et al., 2006). Thus, they support the SDH (Liberman et al., 1974; Lindgren et al., 1985).

\section{Method}

Sixty students whose mother tongue is Arabic and who were studying Hebrew as an L2, and English as an L3/FL, participated in this study. All came from a median socio-economic background, and were enrolled in the $6^{\text {th }}$ grade at regular elementary schools for the Arab sector in northern Israel. These students were categorized by their teachers as being poor in Arabic, Hebrew, and English, with their average grade in all three languages being below 60. Within the school framework, these students began studying Hebrew L2 from $3^{\text {rd }}$ grade, and English L3/FL from $4^{\text {th }}$ grade. The children were chosen at random from four elementary schools in the Galilee re- 
gion of northern Israel, which is characterized by a high concentration of Arab residents. The sample included 32 boys and 28 girls, divided into two groups: the treatment group of 18 girls and 12 boys, and the control group with 10 girls and 20 boys. The average age of the participants was 11.8 years.

\subsection{Tools}

To examine the participants' abilities in meta-linguistic skills, both groups underwent a battery of tests in Arabic, Hebrew, and English. These tests were identical in content, scope and level of difficulty, with nine questions regarding each language and 30 tasks per question. The tests included the spheres of orthography, phonology, morphology, syntax, reading, and reading comprehension.

Orthographic knowledge in Arabic, Hebrew, and English (Alphas $=0.85,0.82,0.79$ ). This task examined the students' ability to identify letters, and the order in which they appear in a word. The student received a number of letters arranged in the wrong order; connecting the letters did not produce a word with any meaning. The student was asked to rearrange the letters in the right order to produce a meaningful word. For example:

The letters in Arabic ك ب ت 1 S. The word

The letters in Hebrew ל ל ת מ מ

The letters in English $\mathbf{r}$ a y d. The word

Phonological knowledge in Arabic, Hebrew, and English (Alphas $=0.87,0.89,0.83$ ). This assignment examined the phonological-analytical abilities of the student in pronouncing the syllables in the words provided. For example:

The word in Arabic نَصَصِيُّن broken down into syllables:

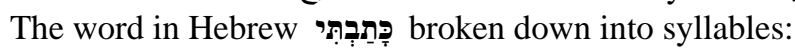

The word in English beautiful broken down into syllables:

Morphological awareness Arabic, Hebrew, and English. This linguistic skill was examined using three tasks:

Identification (Alphas $=0.85,0.86,0.83$ ). The participant was asked to identify the root of the word in both

Arabic and Hebrew, and identify the "stem" that makes up the word in English. For example:

The word in Arabic عَبَرو أits root:

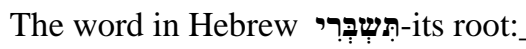

The word in English useless-its stem:

Derivatives (Alphas $=0.82,0.83,0.80$ ). The participant was asked to derive four words from a single term. For example:

The word in Arabic شَرِبَ -derivatives:

The word in Hebrew הִִּ -derivatives:

The word in English readers-derivatives:

Inflection (Alphas $=0.82,0.83,0.85$ ). The participant was asked to change words from singular to plural, demonstrating awareness of orthographical and morphological changes that occur in a word as a result. For example:

The word in Arabic Plural form;

The word in Hebrew

The word in English park Plural form;

Syntactic awareness in Arabic and English. This skill was examined using two tasks:

Correcting sentences (Alphas $=0.88,0.87,0.85$ ). To examine the participant's awareness of proper sentence structure, the participant receives a sentence with incorrect word order, and must rearrange the words to make a proper sentence. For example:

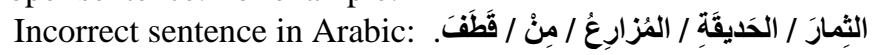

Correct sentence in Arabic:

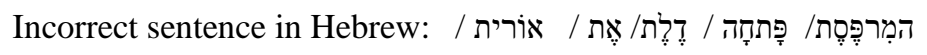

Correct sentence in Hebrew:

Incorrect sentence in English: like/food/Americans/fast/I/.

Correct sentence in English:

Complete sentences (Alphas $=0.87,0.82,0.80$ ). The participant is given an incomplete sentence, and must add a proper connecting word to complete it. For example: 
Sentence in Arabic: . أحْو الِِ الطَقْسِ سَألث:

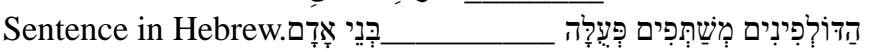

Sentence in English: You need to learn more science.

Reading accuracy in Arabic, Hebrew, and English (Alphas = 0.80, 0.82, 0.80). Each participant received 30 isolated words in all three languages, and was instructed to read them accurately.

Reading comprehension in Arabic, Hebrew, and English (Alphas = 0.89, 0.88, 0.86). Each participant received two texts in each of the three languages. Each text was accompanied by 10 multiple choice questions for a sum total of 20 questions in Arabic, 20 questions in Hebrew and 20 in English. The participant was instructed to read the text silently and then answer the questions, which examine comprehension. The texts matched the Arabic, Hebrew, and English language curricula for $6^{\text {th }}$ grade. The questions were composed by the researcher in consultation with highly experienced teachers in the field. It is important to note that the Arabic, Hebrew, and English groups were formed by a committee of experts in accordance with the Arabic, Hebrew, and English curricula for $6^{\text {th }}$ grade.

To be approved for participation in the reading comprehension assessment for the entire study, the students first completed an examination, and were evaluated by three teachers of Arabic, three teachers of Hebrew, and three teachers of English with long-term experience in teaching these languages to the $6^{\text {th }}$ grade.

\subsection{Procedure}

The participants were divided into an experimental group and a control group, and the three tests in Arabic, Hebrew and English were administered in three stages: The first two consisted of four questions each, while the third included two texts for reading comprehension. All three stages were completed over a three-week period. The test results served as a baseline for comparing the results of the tests administered at the end of the experimental process.

After completion and analysis of the first tests results, a committee of language experts began formulating an intervention program, in consultation with the teachers who conducted the test in English. This program was constructed based on participants' points of strength and weakness. Since almost all participants demonstrated weak abilities in almost every indicator for English, it was decided that the intervention program would focus on the linguistic skills for which the students were examined in this study, which include orthographic, phonological, morphological, syntactical, reading and reading comprehension skills. It's worth noting that the intervention program was distributed among the treatment group by an English teacher who also served as a research assistant, while the control group, which received no intervention, took the tests only before and after the intervention. At the conclusion of the intervention program, all participants underwent the same series of tests in Arabic, Hebrew and English, experimental and control group alike.

The purpose of administering the English tests at the end of the intervention program was to examine whether any change had occurred in the skills practiced in the program. The purpose of the Arabic and Hebrew tests was twofold: to examine any changes in students' achievements in Arabic and/or Hebrew when compared with achievements before the English intervention program, and to determine whether meta-linguistic skills were transferred from English to Arabic and to Hebrew, meaning from the third to second and first languages in accordance with our research question.

The intervention program was designed taking into account the weak and strong competencies of the participants. Since all of the participants exhibited a low level in all skills of English, it was decided to work with the participants on four major aspects, so that all the skills tested were covered in the intervention program. The linguistic aspects are as follows:

1. Decoding-Recognition of letters and their sounds; recognition of the sound of vowels and common combinations of letters, such as: th, ph, oo, ea, ch. Also, learning the pronunciation of common English forms of words, such as: bake-game-made-snake; time-fine-like-bite, etc., and finally learning frequent word endings (for example: tion, sion). All of that was practiced by reading isolated words. In addition, approximately twice a month, an oral practice session was conducted in which a participant was asked to segment a spoken word into phonemes, as well as synthesize phonemes into complete words. This practice was done in order to increase phonological awareness.

2. Vocabulary - Expanding vocabulary was done by flashing frequently-used words, where the participants had to learn their meaning. As a practice of the vocabulary, the participants had to compose sentences using the 
words learned. They also had to translate into English short phrases. In every new session, a repetition of the previously-taught words was made before new words were introduced. All the words learned were given also printed in a list, so the participants could study them at home. Approximately every two weeks, a dictation was conducted on words taken from that list.

3. Grammar-A gradual and systematic instruction of the following grammar subjects was undertaken: the use of "a/an"; the auxiliary verb "to be"; have/has; present simple; present progressive; past simple. The learning of the tenses included declarative sentences, interrogative sentences and negative, using supporting cards which specify the appropriate grammatical rules. The participants practiced all the grammar rules by completing work sheets in class and later at home. The syntax aspect was also learned by an instruction of the syntactical rules regarding the correct order of words in an English sentence. The practice included mixing up the correct order of words in a sentence and requiring participants to reorganize it correctly.

4. Reading - The participants practiced fluent reading of texts with emphasis on speed and accuracy. Exercising reading speed was performed by repeated reading of the same textlparagraph. In the following session, a practice of reading comprehension skills of the same text took place. The comprehension skills and strategies that were practiced were: making predictions and activating prior knowledge, figuring out unknown words, locating information in the text, story retelling and finally giving a title to each paragraph.

In summary, the intervention program was composed of a series of lessons in which English linguistic skills were studied. Both the supporting cards and the work sheets were prepared by the authors themselves. Every session was carried out by a teacher and two students in a quiet and isolated room. From the beginning, the students participating in the program were divided equally and randomly into two groups with 10 members in each group. The lessons for one of the two groups were given by one of the authors who is a qualified remedial teacher. The second group was taught by an English teacher with training in teaching children with learning disabilities. This teacher was subjected to continuous instructions by the authors throughout the program as to the contents of the lessons and as to the appropriate form of instruction. This was to ensure that the lessons given to the two groups were of equal form. The program was spread over five months with classes of 45 minutes each, taking place twice weekly.

At the end of the intervention program, all participants were given the same test batteries in English that were given before the intervention program. This was done in order to test for possible improvement in English linguistic skills, as a result of the intervention program. Afterwards, the test batteries were given also in Hebrew and Arabic, in order to test for possible improvement in the same linguistic skills in $\mathrm{L}_{1}$. Summing up the results will provide possible evidence for the cognitive retroactive transfer hypothesis (CRT).

\section{Results}

To examine the effect of the intervention program on improving linguistic skills, the present study examined language skills in English, Arabic and Hebrew, before and after the intervention period in the treatment group, as compared with the control group, which received no intervention. The significance of the difference between skill levels before and after the intervention was examined using the covariance analysis of the Multivariate Analysis of Variance (One Way MANOVA). Tables 1 and 2 present the means, standard deviations, and the "One Way MANOVA" values on English, Arabic and Hebrew tasks in the experimental and control groups, both before and after intervention.

The MANOVA analysis in Table 1 revealed a significant improvement between the average scores of all language skills for English, Arabic and Hebrew, before and after the intervention, in the treatment group. However, there was no significant improvement between the average scores of the orthographic knowledge for both Arabic and Hebrew language before and after the intervention. The average grade for orthographic knowledge in Arabic before the intervention was $M=22.1$, and $M=22.37$ after the intervention. However, the average grade for Hebrew orthographic knowledge before the intervention was $\mathrm{M}=20.97$, and $\mathrm{M}=21.07$ after the intervention, while the MANOVA revealed a strong significant improvement of English orthographic knowledge before and after the intervention: $\mathrm{F}_{(1,58)}=56.96, p<0.001$. Likewise, the findings in Table 1 point to the fact that the change that occurred in all language skill average grades in English before and after intervention was higher than the change seen in all language skill average grades in both Arabic and Hebrew. However, the change that occurred in the mean scores for all Arabic language skills was higher when compared with the change that occurred in Hebrew language skills before and after the intervention. Nevertheless, the difference between the averages before and after the intervention in all study languages was very strongly significant. 
Table 1. Means (max 30), standard deviations in all language skills for English, Arabic, and Hebrew before and after the intervention in the treatment group, and the covariance analysis values of one-way multivariate (MANOVA-One Way).

\begin{tabular}{|c|c|c|c|c|c|c|}
\hline Language & \multicolumn{2}{|c|}{ English } & \multicolumn{2}{|c|}{ Arabic } & \multicolumn{2}{|c|}{ Hebrew } \\
\hline \multirow{2}{*}{ Skill } & Before & After & Before & After & Before & After \\
\hline & Mean (S. D) & Mean (S. D) & Mean (S. D) & Mean (S. D) & Mean (S. D) & Mean (S. D) \\
\hline \multirow{2}{*}{ Orthographic knowledge } & $18.13(3.53)$ & 25.17 (3.69) & $22.10(3.54)$ & $22.37(3.80)$ & $20.97(3.36)$ & $21.07(3.42)$ \\
\hline & \multicolumn{2}{|c|}{$\mathrm{F}_{(1,58)}=56.96^{* * *}$} & \multicolumn{2}{|c|}{$F_{(1,58)}=0.08$} & \multicolumn{2}{|c|}{$F(1,58)=0.01$} \\
\hline \multirow{2}{*}{ Phonological awareness } & $15.20(3.68)$ & $24.07(3.53)$ & $16.80(3.28)$ & $23.00(3.81)$ & $16.10(3.36)$ & $21.60(3.47)$ \\
\hline & \multicolumn{2}{|c|}{$F_{(1,58)}=90.63^{* * *}$} & \multicolumn{2}{|c|}{$\mathrm{F}_{(1,58)}=45.15^{* * *}$} & \multicolumn{2}{|c|}{$\mathrm{F}_{(1,58)}=38.94^{* * *}$} \\
\hline \multirow{2}{*}{ Morphological awareness-1 } & $13.73(3.25)$ & $19.27(3.74)$ & $14.77(3.75)$ & $18.97(4.71)$ & $14.23(3.19)$ & $17.63(4.01)$ \\
\hline & \multicolumn{2}{|c|}{$\mathrm{F}_{(1,58)}=37.43^{* * * *}$} & \multicolumn{2}{|c|}{$\mathrm{F}_{(1,58)}=14.61^{* * *}$} & \multicolumn{2}{|c|}{$\mathrm{F}_{(1,58)}=13 \cdot 19^{* *}$} \\
\hline \multirow{2}{*}{ Morphological awareness-2 } & 15.27 (3.24) & $22.07(4.08)$ & $19.17(3.03)$ & $24.27(3.00)$ & $18.00(3.07)$ & $21.63(3.05)$ \\
\hline & \multicolumn{2}{|c|}{$\mathrm{F}_{(1,58)}=51.20^{* * *}$} & \multicolumn{2}{|c|}{$F_{(1,58)}=42.86^{* * *}$} & \multicolumn{2}{|c|}{$\mathrm{F}_{(1,58)}=21.15^{* * *}$} \\
\hline \multirow{2}{*}{ Morphological awareness-3 } & $18.63(3.47)$ & $26.30(3.44)$ & $19.53(3.36)$ & 24.67 (3.25) & $18.97(2.81)$ & $23.83(2.78)$ \\
\hline & \multicolumn{2}{|c|}{$F_{(1,58)}=73.98^{* * *}$} & \multicolumn{2}{|c|}{$\mathrm{F}_{(1,58)}=36.15^{* * *}$} & \multicolumn{2}{|c|}{$\mathrm{F}_{(1,58)}=45.47^{* * *}$} \\
\hline \multirow{2}{*}{ Syntactic awareness- 1} & $14.93(3.05)$ & $20.67(3.21)$ & $19.50(3.20)$ & $23.97(2.74)$ & $18.33(3.08)$ & $21.53(2.78)$ \\
\hline & \multicolumn{2}{|c|}{$\mathrm{F}_{(1,58)}=50.30^{* * *}$} & \multicolumn{2}{|c|}{$\mathrm{F}_{(1,58)}=33.74^{* * * *}$} & \multicolumn{2}{|c|}{$\mathrm{F}_{(1,58)}=17.88^{* * *}$} \\
\hline \multirow{2}{*}{ Syntactic awareness-2 } & $18.03(3.44)$ & $24.73(4.14)$ & $21.37(3.90)$ & $25.57(3.00)$ & $19.83(3.77)$ & $23.10(3.98)$ \\
\hline & \multicolumn{2}{|c|}{$\mathrm{F}_{(1,58)}=46.56^{* * *}$} & \multicolumn{2}{|c|}{$\mathrm{F}_{(1,58)}=21.85^{* * *}$} & \multicolumn{2}{|c|}{$\mathrm{F}_{(1,58)}=10.66^{* *}$} \\
\hline \multirow{2}{*}{ Reading accuracy } & $14.67(4.29)$ & $21.10(5.79)$ & $18.63(4.94)$ & 23.13 (5.34) & $17.00(4.32)$ & $20.37(4.82)$ \\
\hline & \multicolumn{2}{|c|}{$\mathrm{F}_{(1,58)}=23.89^{* * *}$} & \multicolumn{2}{|c|}{$\mathrm{F}_{(1,58)}=11 \cdot 47^{* *}$} & $\mathrm{~F}_{(1,58)}$ & $8.10^{* *}$ \\
\hline & $10.13(2.26)$ & $14.83(2.74)$ & $12.03(2.94)$ & 15.63 (3.37) & $11.33(2.23)$ & $14.57(3.10)$ \\
\hline & $F_{(1,58)}=$ & $2.56^{* * *}$ & $F_{(1,58)}$ & $9.44^{* * * *}$ & $F_{(1,58)}=$ & $1.45^{* * *}$ \\
\hline
\end{tabular}

Notes: ${ }^{* * *} p<0.001 ;{ }^{* *} p<0.01$; a-Morphological Awareness-1 = Morphological awareness of identification level; b-Morphological Awareness-2 = Morphological awareness derivatives level; c-Morphological Awareness-3 = Morphological awareness inflection level; d-Syntactic awareness-1 = Correcting sentences level; e-Syntactic awareness- 2 = Completing sentences level.

The control group results presented in Table 2 show a very low improvement rate between the average scores of all language skills for English, Arabic, and Hebrew, before and after the intervention. Furthermore, the MANOVA analysis revealed that there is no significant improvement for the control group in any skill for the languages English, Arabic and Hebrew.

\section{Discussion}

According to the research findings, the research assumption was fully confirmed, meaning that a significant improvement was seen in the treatment group's achievements in all linguistic and meta-linguistic skills after intervention, and in all three languages, except for Arabic and Hebrew orthographic knowledge. This leads to the conclusion that CRT did occur from English L3 to both Arabic L1 and Hebrew L2, in all of the skills investigated in this study, with the sole exception of orthographic knowledge transfer, which was found to be language-specific.

The findings revealed that the improvement rate in all Arabic language skills in the treatment group, before and after the intervention, was higher in comparison with the improvement in Hebrew language skills. This can be explained by the assumption that when an Arab child learns English as an L3 from an Arab teacher, most of the learning/teaching process occurs in Arabic the native language of the learners. Such a process may enhance the level of Arabic among those Arab learners. This assumption is compatible with other research findings 
Table 2. Means (max 30), standard deviations in all language skills for English, Arabic, and Hebrew before and after the intervention period in the control group, and the covariance analysis values of one-way multivariate (MANOVA-One Way).

\begin{tabular}{|c|c|c|c|c|c|c|}
\hline Language & \multicolumn{2}{|c|}{ English } & \multicolumn{2}{|c|}{ Arabic } & \multicolumn{2}{|c|}{ Hebrew } \\
\hline \multirow{2}{*}{ Skill } & Before & After & Before & After & Before & After \\
\hline & Mean (S. D) & Mean (S. D) & Mean (S. D) & Mean (S. D) & Mean (S. D) & Mean (S. D) \\
\hline \multirow{2}{*}{ Orthographic knowledge } & $17.97(3.59)$ & $18.17(3.71)$ & $22.52(4.31)$ & $22.76(4.35)$ & $20.66(3.32)$ & $20.86(3.28)$ \\
\hline & \multicolumn{2}{|c|}{$\mathrm{F}_{(1,58)}=0.104$} & \multicolumn{2}{|c|}{$\mathrm{F}_{(1,58)}=0.03$} & \multicolumn{2}{|c|}{$\mathrm{F}_{(1,58)}=0.07$} \\
\hline \multirow{2}{*}{ Phonological awareness } & $15.45(3.61)$ & $15.79(3.66)$ & $17.79(4.20)$ & $18.28(3.60)$ & $16.55(3.45)$ & $17.21(3.43)$ \\
\hline & \multicolumn{2}{|c|}{$\mathrm{F}_{(1,58)}=0.10$} & \multicolumn{2}{|c|}{$\mathrm{F}_{(1,58)}=0.25$} & \multicolumn{2}{|c|}{$\mathrm{F}_{(1,58)}=0.63$} \\
\hline \multirow{2}{*}{ Morphological awareness- 1} & $13.14(2.90)$ & $13.45(2.89)$ & $15.21(3.16)$ & $15.76(3.28)$ & $14.07(3.08)$ & $14.34(3.10)$ \\
\hline & \multicolumn{2}{|c|}{$\mathrm{F}_{(1,58)}=0.14$} & \multicolumn{2}{|c|}{$F_{(1,58)}=0.51$} & \multicolumn{2}{|c|}{$F_{(1,58)}=0.12$} \\
\hline \multirow{2}{*}{ Morphological awareness-2 } & $15.07(3.09)$ & $15.24(3.08)$ & $19.34(2.87)$ & $19.59(2.88)$ & $17.72(2.72)$ & $18.00(2.78)$ \\
\hline & \multicolumn{2}{|c|}{$\mathrm{F}_{(1,58)}=0.07$} & \multicolumn{2}{|c|}{$\mathrm{F}_{(1,58)}=0.09$} & \multicolumn{2}{|c|}{$\mathrm{F}_{(1,58)}=0.26$} \\
\hline \multirow{2}{*}{ Morphological awareness-3 } & $18.97(3.78)$ & $19.34(3.60)$ & $20.59(3.65)$ & $20.79(3.53)$ & $19.38(2.86)$ & $19.62(2.73)$ \\
\hline & \multicolumn{2}{|c|}{$\mathrm{F}_{(1,58)}=0.13$} & \multicolumn{2}{|c|}{$\mathrm{F}_{(1,58)}=0.06$} & \multicolumn{2}{|c|}{$\mathrm{F}_{(1,58)}=0.07$} \\
\hline \multirow{2}{*}{ Syntactical awareness- 1} & $14.48(3.23)$ & $14.66(3.35)$ & $20.14(3.02)$ & $20.28(2.96)$ & $18.52(3.44)$ & 18.69 (3.39) \\
\hline & \multicolumn{2}{|c|}{$\mathrm{F}_{(1,58)}=0.01$} & \multicolumn{2}{|c|}{$\mathrm{F}_{(1,58)}=0.07$} & \multicolumn{2}{|c|}{$\mathrm{F}_{(1,58)}=0.06$} \\
\hline \multirow{2}{*}{ Syntactic awareness-2 } & $17.62(3.83)$ & $17.86(3.92)$ & $20.66 \quad(3.71)$ & $20.83(3.51)$ & $19.79(3.10)$ & $19.90(3.13)$ \\
\hline & \multicolumn{2}{|c|}{$\mathrm{F}_{(1,58)}=0.05$} & \multicolumn{2}{|c|}{$F_{(1,58)}=0.004$} & \multicolumn{2}{|c|}{$\mathrm{F}_{(1,58)}=0.002$} \\
\hline \multirow{2}{*}{ Reading accuracy } & $15.00(3.86)$ & $15.21(3.74)$ & $18.90(4.38)$ & $19.10(4.46)$ & $17.45(4.09)$ & $17.76(4.02)$ \\
\hline & \multicolumn{2}{|c|}{$\mathrm{F}_{(1,58)}=0.06$} & \multicolumn{2}{|c|}{$F_{(1,58)}=0.10$} & $\mathrm{~F}_{(1,58}$ & 0.14 \\
\hline & $10.28(2.37)$ & $10.45(2.46)$ & $11.52(1.98)$ & $11.79(2.02)$ & 11.31 (1.69) & 11.55 (1.64) \\
\hline & $F_{(1,5}$ & 0.09 & $\mathrm{~F}_{(1,5 \varepsilon}$ & 0.40 & $F_{(1,58}$ & 0.44 \\
\hline
\end{tabular}

Notes: a-Morphological Awareness-1 = Morphological awareness of identification level; b-Morphological Awareness-2 = Morphological awareness derivatives level; c-Morphological Awareness-3 = Morphological awareness inflection level; d-Syntactic awareness-1 = Correcting sentences level; e-Syntactic awareness-2 = Completing sentences level.

(Fung, Wilkinson, \& Moore, 2003; Mukattash, 2003; Schweers, 1999; Sheen, 2001; Tang, 2002). These studies describe how the L1 is currently being used in the L2 classroom, including the explanation of unfamiliar words, teaching pronunciation, clearing up difficult grammatical issues, explaining reading strategies and giving instructions for different tasks. Therefore, it can be assumed that when the process occurs in the opposite direction, the L3 impact will be more on the L1 (Arabic) than on the L2 (Hebrew). That is to say, the improvement in English L3 skills will improve the language skills of Arabic as an L1 more than Hebrew as an L2.

\subsection{Orthographic Knowledge Transfer}

The research findings revealed a significant improvement in English orthographic skills after the intervention program in the treatment group when compared to the performance of the control group, which did not achieve any significant improvement in English orthographic tasks after the experimental period. The improvement in both Arabic and Hebrew orthographic skills among the treatment group was very small after the intervention, and very similar to the control group's achievements. In any case, improvement was not significant in either condition. It is quite likely that the improvement in orthographic skills in both Arabic and Hebrew language was not a result of intervention, or a consequence of transfer from English, but rather due to the cognitive development of the participants. Furthermore, the degree of improvement in both Arabic and Hebrew orthographic knowledge after intervention was much lower than the improvement noted in all other post-intervention Arabic 
and Hebrew skills.

This research finding is also consistent with other studies that report no cross-language transfer of orthographic knowledge (Abu-Rabia, 2001a, Abu-Rabia \& Siegel, 2003; Arab-Moghaddam \& Sénéchal, 2001; SunAlperin \& Wang, 2009; Wang et al., 2006). Abu-Rabia (2001a) examined Russian bilingual students learning English L2. The findings indicate that linguistic skills of L1 tend to transfer to L2, except for orthographic skills, which are language-specific (Abu-Rabia \& Sanitsky, 2010; Deacon et al., 2009; Nassaji \& Geva, 1999; Wang et al., 2003).

In conclusion, the findings indicate that there was no transfer of orthographic skills from English L3 to either Arabic L1 or Hebrew L2, which supports the Script Dependent Hypothesis (Liberman et al., 1974; Lindgren et al., 1985).

\subsection{Phonological Awareness Transfer}

The findings indicate a significant improvement in the treatment group's achievements in phonological awareness skills post-intervention, and in all three languages, despite the fact that this group did not receive intervention in either Arabic or Hebrew. This finding testifies to the transfer of phonological skills from English L3 to Arabic L1 and Hebrew L2. The advancement in the treatment group's achievements in English was higher than in Arabic. However, the improvement in Hebrew was lower than the improvement noted for those same skills in Arabic (the trend was evident in every skill examined by this study). No improvement was recorded in the control group in phonological skills after the experimental period, whether in English, Arabic, or Hebrew, vis-à-vis their achievements before the start of the experiment. This finding confirms the assumption that the transfer of phonological awareness from English L3 to Arabic L1 and to Hebrew L2 does occur, and coincides with the findings of others supporting the transfer of phonological awareness ability from an L1 to an L2 (Abu-Rabia \& Siegel, 2002, 2003; Chiappe et al., 2007; Keung \& Ho, 2009; Laurent \& Martinot, 2010; Saiegh-Haddad \& Geva, 2008; Verhoeven, 2007; Wade-Woolley \& Geva, 2000). This finding also indicates that phonological awareness is not a language-specific skill, and that increased exposure and practice of the sounds of any language may help improve one's meta-linguistic phonological abilities.

\subsection{Morphological Awareness Transfer}

The research findings show a significant improvement in the treatment group's post-intervention achievements in morphological awareness skills (identification, derivation and inflection levels) in English, Arabic, and Hebrew. Furthermore, a significant positive connection was found between the treatment group's post-intervention morphological skills achievements in English, and the post-intervention morphological awareness achievements in both Arabic and Hebrew. The control group showed no improvement in morphological awareness skills in English, Arabic, or Hebrew. Therefore, the treatment group's improved achievements in Arabic and Hebrew morphological awareness can be attributed to the group's improvement in English morphological awareness skills, suggesting the transfer of morphological awareness skills from English as an L3 to Arabic as the L1 and Hebrew as the L2 (Deacon et al., 2009; Kahn-Horwitz et al., 2007; Schiff \& Calif, 2007). At the same time, this finding also contradicts those of others (Jarvis \& Odlin, 2000; Ramirez et al., 2010; Saiegh-Haddad \& Geva, 2008; Wang et al., 2009), who contended that only a one-way transfer of morphological skills was possible, from languages with transparent orthography (such as Arabic, Spanish, Finnish and Korean) to languages with deep orthography (such as English), and not in the other direction. The present findings can be explained by the fact that this study examined meta-linguistic morphological skills common to the study languages of English, Arabic, and Hebrew. Therefore, we can conclude, despite the difference in the composition of the morphological systems of each language, that there are basic morphological skills that are common to all alphabetic languages, and which are transferable between languages, regardless of their orthographic and morphological depths.

\subsection{Syntactic Awareness Transfer}

The findings show a significant improvement in the grades of the treatment group in syntax skills when completing and correcting sentences before and after the intervention in English, Arabic, and Hebrew. No corresponding change was seen among the control group in this skill in any of the study languages, and whether at the beginning or end of the experiment, demonstrating the influence of the intervention program on the treatment 
group's achievements. The advancement in the treatment group's achievements in English was higher than that for both Arabic and Hebrew. Overall, the findings prove in the clearest way possible that a transfer of syntactic awareness skills from English L3 to both Arabic L1 and Hebrew L2 did occur, which is identical to the findings of others (Abu-Rabia \& Sanitsky, 2010; Abu-Rabia \& Siegel, 2003; Dussias \& Scaltz, 2008; Droop \& Verhoeven, 1998). In contrast, the current findings are inconsistent with other research findings, which contended that syntactic awareness is a language-specific skill and not transferred between languages. (Chiappe \& Siegel, 1999; Chiappe et al., 2002; Lesaux \& Siegel, 2003; Lipka et al., 2005). Chiappe and colleagues (2002), and Lipka and colleagues (2005) claimed that exposure to English instruction for more than three years was not enough to make English L2 children' syntactic awareness in English comparable with that of L1 speakers, an argument that contradicts the findings of the present study. We can explain the findings by the fact that syntactic awareness is a feature of linguistic logic that is not language-specific; consequently, exposure to any language can help develop good meta-linguistic syntax skills that can be transferable between languages, regardless of the depth of the language's orthography.

\subsection{Reading Accuracy Transfer}

Unlike the control group, the treatment group demonstrated a significant post-intervention improvement in reading accuracy in English, thus validating the influence of the intervention program. A significant improvement was also seen in the treatment group's achievements in reading accuracy after the intervention, both in Arabic and in Hebrew, despite the fact that the group received no intervention in these languages, proving the transfer of word-identifying skills from English L2 to both Arabic L1 and Hebrew L2. Furthermore, in reading accuracy as in other skills, the improvement in the treatment group's achievements in English was higher than for the same skills in Arabic and Hebrew. This finding is similar to those studies that support the cross-language transfer of word-identifying skills (Abu-Rabia \& Siegel, 2002; da Fontoura \& Siegel, 1995; Durgunoglu et al., 1993; Geva \& Siegel, 2000; Morfidi, et al., 2007). We can explain this finding by suggesting that exposure to linguistic and meta-linguistic skills of one language will improve reading accuracy skills, which are then transferable to other languages, regardless of the depth of the language's orthography. According to Durgunoglu and colleagues (1993), learning linguistic and meta-linguistic skills of a language will improve reading skills, which are transferable between alphabetic languages.

\subsection{Reading Comprehension Transfer}

The findings indicate a significant and meaningful improvement in reading comprehension skills among the treatment group in English, Arabic and Hebrew, both pre- and post-intervention, though the level of improvement in Arabic and Hebrew was lower than that noted for those same skills in English. No improvement was noted between the control group's reading comprehension test results before and after the experiment, proving the effectiveness of the intervention program for the treatment group's achievements. These findings indicate that a transfer of reading comprehension skills from English as an L3 to Arabic as an L1 and Hebrew as an L2 did occur.

The finding of CRT of reading comprehension skills is similar to those of other studies that proved that reading comprehension abilities are transferable from a L1 to L2 (Proctor, August, Carlo, \& Snow, 2006; Kiffer \& Lesaux, 2008; Kahn-Horwitz et al., 2005; Van der Leij et al., 2010; Zhang \& Koda, 2008). In contrast, the current findings contradict those of others (Akamatsu, 2003; Garcia, 1991; Guo \& Roehrig, 2011; Verhoeven, 2000), which contend that there is no cross-language transfer of language components that can contribute to L2 reading comprehension abilities. We can explain the findings by suggesting that increased exposure to any language skills will improve reading comprehension abilities, which are then transferable between languages, regardless of the language's orthographic features.

\section{General Discussion}

The findings indicate a significant post-intervention improvement among the treatment group in all linguistic and meta-linguistic skills, including orthographic knowledge, phonological awareness, morphological awareness, syntactic awareness, reading accuracy and reading comprehension skills in English L3. We then saw in turn a significant improvement among the same group in the same skills in both Arabic L1 and Hebrew L2, except for 
orthographic knowledge, despite the fact that this group did not receive intervention in either Arabic or Hebrew. That means that transfer of linguistic and meta-linguistic skills from English as an L3, to Arabic as an L1, and Hebrew as an L2, did occur, except for orthographic knowledge skills, which were found to be language-specific and which were not transferred from L3 to L1 or L2. However, no improvement was seen in these languages after the experiment among the control group, which did not receive any intervention. This finding therefore validates the CRT hypothesis.

The research results can be most practically applied in the sphere of language education. Though it is quite common for teachers to work in separate language teams, this study offers a new approach that should be brought to the attention of supervisors, principals, curriculum coordinators, and teachers. Since many linguistic and meta-linguistic skills are apparently shared by different languages, and especially the alphabetic ones, and since such skills have been found to be transferable from one language to another, improving students' achievements in one language can bring about similar improvements in others. Therefore, a strong case can indeed be made for the need for, and advantage of, all language-teaching teams cooperating and working together. This could be in the form of at least one session a week for joint lesson planning, establishing special study units, joint sessions and lesson plans, and joint monitoring and review of student progress in all languages offered at a given school. This kind of teamwork and cooperation may also help alert educators to the strengths of individual students in a certain language, and even offer options for using transference to boost such strengths in a different one.

This study's conclusions can also have major implications for helping students diagnosed with learning difficulties and/or disabilities. Usually, such students are exempt from learning an L2 and an L3, and are directed to concentrate first and foremost on developing proper skills in their mother tongue. The conclusions of this study may allow this approach to be reconsidered, since it may be advisable to prepare a work plan specifically tailored to the learning capabilities of the weaker students, in order to specifically help improve their achievements in L3 skills, which in turn could lead to similar improvements in their L1 and L2 skills.

\section{References}

Abd El-Minem, F. M. (1987). Elm Al-Sarf. Jerusalem: Al-Taufik Press.

Abu-Rabia, S. (1997a). Verbal and Working Memory Skills of Bilingual Hebrew-English Speaking Children. International Journal of Psycholinguistics, 13, 25-40.

Abu-Rabia, S. (1997b). Language Proficiency in Four Languages: The Case of Circassians in Israel. Curriculum and Teaching, 18, 27-58.

Abu-Rabia, S. (1998). Reading Arabic Texts: Effects of Text Type, Reader Type and Vowelization. Reading and Writing: An Interdisciplinary Journal, 10, 106-119. http://dx.doi.org/10.1023/A:1007906222227

Abu-Rabia, S. (2001a). Testing the Independence Hypothesis among Native Adult Bilingual Russian-English Students. Journal of Psycholinguistic Research, 30, 437-455. http://dx.doi.org/10.1023/A:1010425825251

Abu-Rabia, S. (2001b). The Role of Vowels in Reading Semitic Scripts: Data from Arabic and Hebrew. Reading and Writing: An Interdisciplinary Journal, 14, 39-59. http://dx.doi.org/10.1023/A:1008147606320

Abu-Rabia, S. (2002). Reading in a Root-Based Morphology Language: The Case of Arabic. Journal of Research in Reading, 25, 299-309. http://dx.doi.org/10.1111/1467-9817.00177

Abu-Rabia, S. (2007). The Role of Morphology and Short Vowelization in Reading Arabic among Normal and Dyslexic Readers in Grades 3, 6, 9, and 12. Journal of Psycholinguistic Research, 36, 89-106. http://dx.doi.org/10.1007/s10936-006-9035-6

Abu-Rabia, S., \& Blueistin-Danon, D. (2012). A Study into the Results of an Intervention Program of Linguistic Skills in English (L2) and Its Effect on Hebrew (L1) among Poor Readers: An Examination of the Cognitive-Retroactive Transfer (CRT) Hypothesis. Open Journal of Modern linguistics, 2, 131-189. http://dx.doi.org/10.4236/ojml.2012.24017

Abu-Rabia, S., \& Saliba, F. (2008). The Lexical Status of Basic Arabic Verb Morphemes among Dyslexic Children. Australian Journal of Learning Difficulties, 13, 115-144. http://dx.doi.org/10.1080/19404150802380589

Abu-Rabia, S., \& Sanitsky, E. (2010). Advantages of Bilinguals over Monolinguals in Learning a Third Language. Journal of Bilingual Research, 33, 173-199. http://dx.doi.org/10.1080/15235882.2010.502797

Abu-Rabia, S., \& Siegel, L. S. (2002). Reading, Syntactic, Orthographic, and Working Memory Skills of Bilingual ArabicEnglish Speaking Canadian Children. Journal of Psycholinguistic Research, 31, 661-678. http://dx.doi.org/10.1023/A:1021221206119 
Abu-Rabia, S., \& Siegel, L. S. (2003). Reading Skills in Three Orthographies: The Case of Trilingual Arabic-Hebrew-EnglishSpeaking Arab Children. Reading and Writing, 16, 611-634. http://dx.doi.org/10.1023/A:1025838029204

Abu-Rabia, S., \& Taha, H. (2006). Reading in Arabic Orthography: Characteristics, Research Findings, and Assessment. In R. M. Joshi, \& P. G. Aaron (Eds.), Handbook of Orthography and Literacy (pp. 321-338). Lawrence Erlbaum Associates.

Abu-Rabia, S., Shakkour, W., \& Siegel, L. S. (2013). Cognitive Retroactive Transfer (CRT) of Language Skills among Bilingual Arabic-English Readers. Bilingual Research Journal, 36, 1-19. http://dx.doi.org/10.1080/15235882.2013.775975

Adams, M. J. (1990). Beginning to Read: Thinking and Learning about Print. Cambridge, MA: MIT Press.

Akamatsu, N. (2003). The Effects of First Language Orthographic Features on Second Language Reading in Text. Language Learning, 53, 207-231. http://dx.doi.org/10.1111/1467-9922.00216

Alderson, J. C. (1993). The Relationship between Grammar and Reading in English for Academic Purposes Test Battery. In D. Douglas, \& C. Chappelle (Eds.), A New Decade of Language Testing Research: Selected Papers from the 1990 Language Testing Research Colloquium. Alexandria, VA: TESOL.

Alderson, C., \& Urquhart, A. (1988). This Test Is Unfair: I’m not an Economist. In P. Carrell, J. Devine, \& D. Eske (Eds.), Interactive Approaches to Second Language Reading. Cambridge: Cambridge University Press. http://dx.doi.org/10.1017/CBO9781139524513.018

Al-Tamimi, Y., \& Rabab’ah, G. (2007). The Relationship between Phonological Awareness and Word Reading. Poznań Studies in Contemporary Linguistics, 43, 5-21. http://dx.doi.org/10.2478/v10010-007-0011-6

Arab-Moghaddam, M., \& Sénéchal, M. (2001). Orthographic and Phonological Processing Skills in Reading and Spelling in Persian/English Bilinguals. International Journal of Behavioral Development, 25, 140-147. http://dx.doi.org/10.1080/01650250042000320

Azzam, R. (1989). Orthography and Reading of the Arabic Language. In P. G. Aaron, \& R. M. Joshi (Eds.), Reading and Writing Disorders in Different Orthographic Orthographic Systems (pp. 203-218). Dordrecht: Kluwer Academic Publishers. http://dx.doi.org/10.1007/978-94-009-1041-6_12

Badian, N. A. (1995). Predicting Reading Ability over the Long Term: The Changing Roles of Letter Naming, Phonological Awareness and Orthographic Processing. Annals of Dyslexia, 45, 79-96. http://dx.doi.org/10.1007/BF02648213

Ball, E. (1993). Assessing Phoneme Awareness. Language, Speech, and Hearing Services in Schools, 24, 130-139.

Bialystok, E., Luk, G., \& Kwan, E. (2005). Bilingualism, Biliteracy, and Learning to Read: Interactions among Languages and Writing Systems. Scientific Studies of Reading, 9, 43-61. http://dx.doi.org/10.1207/s1532799xssr0901_4

Bindman, M. (2004). Grammatical Awareness across Languages and the Role of Social Context: Evidence from English and Hebrew. In T. Nunes, \& P. Bryant (Eds.), Handbook of Children's Literacy (pp. 691-709). Dordrecht: Kluwer Academic Publishers.

Byrne, B. (1996). The Learnability of the Alphabetic Principle: Children's Initial Hypotheses about How Print Represents Spoken Language. Applied Psycholinguistics, 17, 401-426. http://dx.doi.org/10.1017/S0142716400008171

Carlisle, J. F. (1995). Morphological Awareness and Early Reading Achievement. In L. B. Feldman (Ed.), Morphological Aspects of Language Processing (pp. 189-209). Hillsdale, NJ: Erlbaum.

Carlisle, J. F., \& Stone, C. A. (2003). The Effects of Morphological Structure on Children's Reading of Derived Words in English. In E. M. Assink, \& D. Sandra (Eds.), Reading Complex Words: Cross Language Studies (pp. 27-52). New York: Kluwer Academic. http://dx.doi.org/10.1007/978-1-4757-3720-2__2

Carroll, S. (2000). Input and Evidence: The Raw Material of Second Language Acquisition. Amsterdam: John Benjamin's.

Cheung, H., Chan, M., \& Chong, K. (2007). Use of Orthographic Knowledge in Reading by Chinese-English Bi-Scriptal Children. Language Learning, 57, 469-505. http://dx.doi.org/10.1111/j.1467-9922.2007.00423.x

Chiappe, P., Glaeser, B., \& Ferko, D. (2007). Speech Perception, Vocabulary and the Development of Reading Skills in English among Korean- and English-Speaking Children. Journal of Educational Psychology, 99, 154-166. http://dx.doi.org/10.1037/0022-0663.99.1.154

Chiang, P., \& Rvachew, S. (2007). English-French Bilingual Children’s Phonological Awareness and Vocabulary Skills. Canadian Journal of Applied Linguistics, 10, 293-308.

Chiappe, P., \& Siegel, L. S. (1999). Phonological Awareness and Reading Acquisition in English- and Punjabi-Speaking Canadian Children. Journal of Educational Psychology, 91, 20-28. http://dx.doi.org/10.1037/0022-0663.91.1.20

Chiappe, P., Siegel, L., \& Gottardo, A. (2002). Reading-Related Skills of Kindergartners from Diverse Linguistic Backgrounds. Applied Psycholinguistics, 23, 95-116. http://dx.doi.org/10.1017/S014271640200005X

Chiappe, P., Siegel, L. S., \& Wade-Woolley, L. (2002). Linguistic Diversity and the Development of Reading Skills: A 
Longitudinal Study. Scientific Studies of Reading, 6, 369-400. http://dx.doi.org/10.1207/S1532799XSSR0604_04

Cisero, C. A., \& Royer, J. M. (1995). The Development and Cross-Language Transfer of Phonological Awareness. Contemporary Educational Psychology, 20, 275-303. http://dx.doi.org/10.1006/ceps.1995.1018

Cromdal, J. (1999). Childhood Bilingualism and Metalinguistic Skills: Analysis and Control in Young Swedish-English Bilinguals. Applied Psycholinguistics, 20, 1-20. http://dx.doi.org/10.1017/S0142716499001010

Cummins, J. (1979). Linguistic Interdependence and the Educational Development of Bilingual Children. Review of Educational Research, 49, 222-251.

Cummins, J. (1981). The Role of Primary Language Development in Promoting Educational Success for Language Minority Students. In California State Department of Education (Ed.), Schooling and Language Minority Students: A Theoretical Rationale (pp. 3-49). Los Angeles, CA: California State University. http://dx.doi.org/10.3102/00346543049002222

da Fontoura, H. A., \& Siegel, L. S. (1995). Reading, Syntactic, and Working Memory Skills of Bilingual Portuguese-English Canadian Children. Reading and Writing: An Interdisciplinary Journal, 7, 139-153.

http://dx.doi.org/10.1007/BF01026951

D’Angiulli, A., Siegel, L. S., \& Serra, E. (2001). The Development of Reading in English and Italian in Bilingual Children. Applied Psycholinguistics, 22, 479-507. http://dx.doi.org/10.1017/S0142716401004015

Davidson, D., Raschke, V. R., \& Pervez, J. (2010). Syntactic Awareness in Young Monolingual and Bilingual (Urdu-English) Children. Cognitive Development, 25, 166-182. http://dx.doi.org/10.1016/j.cogdev.2009.07.003

Deacon, S. H., \& Kirby, J. R. (2004). Morphological Awareness: Just “More Phonological”? The Roles of Morphological and Phonological Awareness in Reading Development. Applied Psycholinguistics, 25, 223-238. http://dx.doi.org/10.1017/S0142716404001110

Deacon, S. H., Wade-Woolley, L., \& Kirby, J. R. (2009). Flexibility in Young Second-Language Learners: Examining the Language Specificity of Orthographic Processing. Journal of Research in Reading, 32, 215-229.

http://dx.doi.org/10.1111/j.1467-9817.2009.01392.x

de Jong, P. F., \& Van der Leij, A. (1999). Specific Contributions of Phonological Abilities to Early Reading Acquisition: Results from a Dutch Latent Variable Longitudinal Study. Journal of Educational Psychology, 91, 450-476. http://dx.doi.org/10.1037/0022-0663.91.3.450

Droop, M., \& Verhoeven, L. (1998). Background Knowledge, Linguistic Complexity, and Second-Language Reading Comprehension. Journal of Literacy research, 30, 253-271. http://dx.doi.org/10.1080/10862969809547998

Durgunoglu, A. Y. (2002). Cross-Linguistic Transfer in Literacy Development and Implications for Language Learners. Annals of Dyslexia, 52, 189-204. http://dx.doi.org/10.1007/s11881-002-0012-y

Durgunoglu, A. Y., Mir, M., \& Ariño-Martí, S. (2002). The Relationship between Bilingual Children’s Reading and Writing in Their Two Languages. In S. Randsdell, \& M. L. Barbier (Eds.), Psycholinguistic Approaches to Understanding Second Language Writing (pp. 81-100). Dordrecht: Kluwer.

Durgunoglu, A. Y., Nagy, W. E., \& Hancin-Bhatt, B. J. (1993). Cross-Language Transfer of Phonological Awareness. Journal of Educational Psychology, 85, 453-465. http://dx.doi.org/10.1037/0022-0663.85.3.453

Durgunoglu, A. Y., \& Oney, B. (1999). A Cross-Linguistic Comparison of Phonological Awareness and Word Recognition. Reading and Writing: An Interdisciplinary Journal, 11, 281-299. http://dx.doi.org/10.1023/A:1008093232622

Dussias, P. E., \& Scaltz, T. R. C. (2008). Spanish-English L2 Speakers’ Use of Subcategorization Bias Information in the Resolution of Temporary Ambiguity during Second Language Reading. Acta Psychologia, 128, 501-513.

http://dx.doi.org/10.1016/j.actpsy.2007.09.004

Ehri, L. C. (1992). Reconceptualizing the Development of Sight Word Reading and Its Relationship to Recoding. In P. Gough, L. Ehri, \& R. Treiman (Eds.), Reading Acquisition (pp. 107-143). Hillsdale, NJ: Lawrence Erlbaum.

Ehri, L. C. (1997). Sight Word Learning in Normal Readers and Dyslexia. In B. Blachman (Eds.), Foundations of Reading Acquisition and Dyslexia: Implications for Early Intervention (pp. 163-189). Mahweh, NJ: Erlbaum.

Frost, L., Kaplan, S. W., Cohen, T. E., Henzi, V., Kandel, E. R., \& Hawkins, R. D. (1997). A Simplified Preparation for Relating Cellular Events to Behavior: Contribution of LE and Unidentified Siphon Sensory Neurons to Mediation and Habituation of the Aplysia Gill and Siphon Withdrawal Reflex. Journal of Neuroscience, 17, 2900-2913.

Fung, I. Y. Y., Wilkinson, I. A. G., \& Moore, D. W. (2003). L1-Assisted Reciprocal Teaching to Improve ESL Students' Comprehension of English Expository Text. Learning and Instruction, 13, 1-31. http://dx.doi.org/10.1016/S0959-4752(01)00033-0

Galambos, S. J., \& Goldin-Meadow, S. (1990). The Effects of Learning Two Languages on Levels of Metalinguistic Awareness. Cognition, 34, 1-56. http://dx.doi.org/10.1016/0010-0277(90)90030-N

Garcia, G. E. (1991). Bilingualism, Second Language Acquisition, and the Education of Chicano Language Minority Students. In R. R. Valencia (Ed.), Chicano School Failure and Success: Research and Policy Agendas for the 1990s. New 
York: Falmer.

Geva, E. (1995). Orthography and Cognitive Processing in Learning to Read English and Hebrew. In I. Taylor, \& D. R. Olson (Eds.), Scripts and Literacy (pp. 277-291). Dordrecht: Kluwer. http://dx.doi.org/10.1007/978-94-011-1162-1_18

Geva, E., \& Siegel, L. (2000). Orthographic and Cognitive Factors in the Concurrent Development of Basic Reading Skills in Two Languages. Reading and Writing: An Interdisciplinary Journal, 12, 1-30. http://dx.doi.org/10.1023/A:1008017710115

Geva, E., Yaghoubzadeh, Z., \& Schuster, B. (2000). Understanding Individual Differences in Word Recognition Skills of ESL Children. Annals of Dyslexia, 50, 121-154. http://dx.doi.org/10.1007/s11881-000-0020-8

Gillon, G. (2002). Follow-Up Study Investigating Benefits of Phonological Awareness Intervention for Children with Spoken Language Impairment. International Journal of Language and Communication Disorders, 37, 381-400. http://dx.doi.org/10.1080/1368282021000007776

Goswami, U., \& Bryant, P. E. (1990). Phonological Skills and Learning to Read. Hillsdale, NJ: Lawrence Erlbaum.

Gottardo, A., Yan, B., Siegel, L. S., \& Wade-Woolley, L. (2001). Factors Related to English Reading Performance in Children with Chinese as a First Language: More Evidence of Cross-Language Transfer of Phonological Processing. Journal of Educational Psychology, 93, 530-542. http://dx.doi.org/10.1037/0022-0663.93.3.530

Guo, Y., \& Roehrig, A. D. (2011). Roles of General versus Second Language (L2) Knowledge in L2 Reading Comprehension. Reading in a Foreign Language, 23, 42-64.

Jarvis, S., \& Odlin, T. (2000). Morphological Type, Spatial Reference, and Language Transfer. Studies in Second Language Acquisition, 22, 535-556. http://dx.doi.org/10.1017/S0272263100004034

Just, M. A., \& Carpenter, P. A. (1987). The Psychology of Reading and Language Comprehension. Boston, MA: Allyn and Bacon.

Kahn-Horwitz, J., Shimron, J., \& Sparks, R. L. (2005). Predicting Foreign Language Reading Achievement in Elementary School Students. Reading and Writing, 18, 527-558. http://dx.doi.org/10.1007/s11145-005-3179-x

Katz, L., \& Frost, L. (1992). Reading in Different Orthographies: The Orthographic Depth Hypothesis. In R. Frost, \& L. Katz (Eds.), Orthography, Phonology Morphology, and Meaning (pp. 67-84). Amsterdam: Elsevier.

Keung, Y. C., \& Ho, C. S. H. (2009). Transfer of Reading-Related Cognitive Skills in Learning to Read Chinese (L1) and English (L2) among Chinese Elementary School Children. Contemporary Educational Psychology, 34, 103-112. http://dx.doi.org/10.1016/j.cedpsych.2008.11.001

Kieffer, M. J., \& Lesaux, N. K. (2008). The Role of Derivational Morphology in the Reading Comprehension of SpanishSpeaking English Language Learners. Reading and Writing, 21, 783-804. http://dx.doi.org/10.1007/s11145-007-9092-8

Kim, Y. S. (2009). The Relationship between Home Literacy Practices and Developmental Trajectories of Emergent Literacy and Conventional Literacy Skills for Korean Children. Reading and Writing, 22, 57-84. http://dx.doi.org/10.1007/s11145-007-9103-9

Koda, K. (2007). Reading and Language Learning: Crosslinguistic Constraints on Second Language Reading Development. Language Learning, 57, 1-44. http://dx.doi.org/10.1111/0023-8333.101997010-i1

Laurent, A., \& Martinot, C. (2010). Bilingualism and Phonological Awareness: The Case of Bilingual (French-Occitan) Children. Reading and Writing, 23, 435-452. http://dx.doi.org/10.1007/s11145-009-9209-3

Lefrançois, P., \& Armand, F. (2003). The Role of Phonological and Syntactic Awareness in Second Language Reading. The Case of Spanish-Speaking Learners of French. Reading and Writing: An Interdisciplinary Journal, 16, 219-246. http://dx.doi.org/10.1023/A:1022874425314

Leiken, M., Share, D., \& Schwartz, M. (2005). Difficulties in L2 Hebrew Reading in Russian-Speaking Second Graders. Reading and Writing: An Interdisciplinary Journal, 18, 455-472. http://dx.doi.org/10.1007/s11145-005-8919-4

Lesaux, N. K., \& Siegel, L. S. (2003). The Development of Reading in Children Who Speak English as a Second Language. Developmental Psychology, 39, 1005-1019. http://dx.doi.org/10.1037/0012-1649.39.6.1005

Liberman, I. Y., Shankweiler, D., Fischer, F. W., \& Carter, B. (1974). Explicit Syllable and Phoneme Segmentation in the Young Child. Journal of Experimental Child Psychology, 18, 201-212. http://dx.doi.org/10.1016/0022-0965(74)90101-5

Lindgren, S. D., DeRenzi, E., \& Richman, L. C. (1985). Cross-National Comparison of Developmental Dyslexia in Italy and the United States. Child Development, 56, 1404-1417.

Lipka, O., Siegel, L. S., \& Vukovic, R. (2005). The Literacy Skills of English Language Learners in Canada. Learning Disabilities Research \& Practice, 20, 39-49. http://dx.doi.org/10.1111/j.1540-5826.2005.00119.x

Lyon, G. R., Fletcher, J. M., \& Barnes, M. C. (2003). Learning Disabilities. In E. J. Mash, \& R. A. Barkley (Eds.), Child Psychopathology (2nd ed., pp. 520-586). New York: Guilford Press. 
Mahony, D., Singson, M., \& Mann, V. (2000). Reading Ability and Sensitivity to Morphological Relations. Reading and Writing: An Interdisciplinary Journal, 12, 191-218. http://dx.doi.org/10.1023/A:1008136012492

Mann, V. (1998). Language Problems and Early Reading. In B. Y. L. Wong (Ed.), Learning about Learning Disabilities (pp. 163-202). San Diego, CA: Academic Press.

Mann, V. A., \& Wimmer, H. (2002). Phoneme Awareness and Pathways into Literacy: A Comparison of German and American Children. Reading and Writing: An Interdisciplinary Journal, 15, 653-682. http://dx.doi.org/10.1023/A:1020984704781

McBride-Chang, C., Cho, J. R., Liu, H. Y., Wagner, R. K., Shu, H., Zhou, A., \& Muse, A. (2005). Changing Models across Cultures: Associations of Phonological Awareness and Morphological Structure Awareness with Vocabulary and Word Recognition in Second Graders from Beijing, Hong Kong, Korea, and the United States. Journal of Experimental Child Psychology, 92, 140-160. http://dx.doi.org/10.1016/j.jecp.2005.03.009

McBride-Chang, C., Tong, X., Shu, H., Wong, A. M. Y., Leung, K. W., \& Tardif, T. (2008). Syllable, Phoneme, and Tone: Psycholinguistic Units in Early Chinese and English Word Recognition. Scientific Studies of Reading, 12, 171-194. http://dx.doi.org/10.1080/10888430801917290

Morfidi, E., Van der Leij, A., de Jong, P. F., Scheltinga, F., \& Bekebrede, J. (2007). Reading in Two Orthographies: A Cross-Linguistic Study of Dutch Average and Poor Readers Who Learn English as a Second Language. Reading and Writing: An Interdisciplinary Journal, 20, 753-784. http://dx.doi.org/10.1007/s11145-006-9035-9

Mukattash, L. (2003). Towards a New Methodology for Teaching English to Arab Learners. International Journal of ArabicEnglish Studies, 4, 211-234.

Nassaji, H., \& Geva, E. (1999). The Contribution of Phonological and Orthographic Processing Skills to Adult ESL Reading: Evidence from Native Speakers of Farsi. Applied Psycholinguistics, 20, 241-267. http://dx.doi.org/10.1017/S0142716499002040

Perfetti, C. A. (1985). Reading Ability. New York: Oxford University Press.

Perfetti, C. A. (2003). The Universal Grammar of Reading. Scientific Studies of Reading, 7, 3-24. http://dx.doi.org/10.1207/S1532799XSSR0701_02

Proctor, C. P., August, D., Carlo, M. S., \& Snow, C. E. (2006). The Intriguing English Reading Comprehension. Journal of Educational Psychology, 98, 159-169. http://dx.doi.org/10.1037/0022-0663.98.1.159

Ramirez, G., Chen, X., Geva, E., \& Kiefer, H. (2010). Morphological Awareness in Spanish-Speaking English Language Learners: Within and Cross-Language Effects on Word Reading. Reading and Writing: An Interdisciplinary Journal, 23, 337-358. http://dx.doi.org/10.1007/s11145-009-9203-9

Ravid, D. (2001). Learning to Spell in Hebrew: Phonological and Morphological Factors. Reading and Writing: An Interdisciplinary Journal, 14, 459-485. http://dx.doi.org/10.1023/A:1011192806656

Ryan, A., \& Meara, P. (1991). The Case of Invisible Vowels: Arabic Speakers Reading English Words. Reading in a Foreign Language, 7, 531-539.

Rayner, K., \& Pollatsek, A. (1989). The Psychology of Reading. Englewood Cliffs, NJ: Prentice Hall.

Rayner, K., \& Pollatsek, A. (1994). The Psychology of Reading. Englewood Cliffs, NJ: Prentice Hall.

Saiegh-Haddad, E. (2005). Correlates of Reading Fluency in Arabic: Diglossic and Orthographic Factors. Reading and Writing: An Interdisciplinary Journal, 18, 559-582. http://dx.doi.org/10.1007/s11145-005-3180-4

Saiegh-Hadadd, E., \& Geva, E. (2008). Morphological Awareness, Phonological Awareness, and Reading in English-Arabic Bilingual Children. Reading and Writing: An Interdisciplinary Journal, 21, 481-504. http://dx.doi.org/10.1007/s11145-007-9074-x

Scanlon, D. M., \& Vellution, F. R. (1997). A Comparison of the Instructional Backgrounds and Cognitive Profiles of Poor, Average, and Good Readers Who Were Initially Identified as at Risk for Reading Failure. Scientific Studies of Reading, 1, 191-215. http://dx.doi.org/10.1207/s1532799xssr0103_2

Sheen, R. (2001). Contrastive Analysis in Language Teaching: Time to Come in from the Cold. Academic Exchange Quarterly, 5, 119-124.

Schiff, R., \& Calif, S. (2007). Role of Phonological and Morphological Awareness in L2 Oral Word Reading. Language Learning, 57, 271-298. http://dx.doi.org/10.1111/j.1467-9922.2007.00409.x

Schwarzwald, O. R. (2001). Modern Hebrew. Languages of the World/Materials, 127. Munich: Lincom Europe.

Schweers, C. (1999). Using L1 in the L2 Classroom. English Teaching Forum, 37, 6-9.

Shimron, J. (1993). The Role of Vowels in Reading: A Review of Studies of English and Hebrew. Psychological Bulletin, 114, 52-67. http://dx.doi.org/10.1037/0033-2909.114.1.52

Shimron, J., \& Sivan, T. (1994). Reading Proficiency and Orthography: Evidence from Hebrew and English. Language 
Learning, 44, 5-27.

Shiotsu, T. (2009). Reading Ability and Components of Word Recognition Speed: The Case of L1-Japanese EFL Learners. In Z. Han, \& N. Anderson (Eds.), Second Language Reading Research and Instruction (pp. 15-37). Ann Arbor, MI: University of Michigan Press.

Snow, C. E., Burns, M. S., \& Griffin, P. (1998). Preventing Reading Difficulties in Young Children. Washington DC: National Research Council.

Snow, C. E., \& Sweet, A. P. (2003). Reading for Comprehension. In A. P. Sweet, \& C. E. Snow (Eds.), Rethinking Reading Comprehension. New York: The Guilford Press.

Stanovich, K. E. (1986). Matthew Effects in Reading: Some Consequences of Individual Differences in the Acquisition of Literacy. Reading Research Quarterly, 21, 360-405.

Sun-Alperin, M. K., \& Wang, M. (2009). Cross-Language Transfer of Phonological and Orthographic Processing Skills in Spanish-Speaking Children Learning to Read and Spell in English. Reading and Writing: An Interdisciplinary Journal, 24, 591-614. http://dx.doi.org/10.1007/s11145-009-9221-7

Tang, J. (2002). Using L1 in the English Classroom. English Teaching Forum, 40, 36-43.

Van der Leij, A., Bekebrede, J., \& Kotterink, M. (2010). Acquiring Reading and Vocabulary in Dutch and English: The Effect of Concurrent Instruction. Reading and Writing: An Interdisciplinary Journal, 23, 415-434. http://dx.doi.org/10.1007/s11145-009-9207-5

Verhoeven, L. (2000). Components in Early Second Language Reading and Spelling. Scientific Studies of Reading, 4, 313330. http://dx.doi.org/10.1207/S1532799XSSR0404_4

Verhoeven, L. (2007). Early Bilingualism, Language Transfer, and Phonological Awareness. Applied Psycholinguistics, 28, 425-439. http://dx.doi.org/10.1017/S0142716407070233

Wade-Woolley, L., \& Geva, E. (2000). Processing Novel Phonemic Contrasts in the Acquisition of L2 Word Reading. Scientific Studies of Reading, 4, 295-311. http://dx.doi.org/10.1207/S1532799XSSR0404_3

Wade-Woolley, L., \& Siegel, L. S. (1997). The Spelling Performance of ESL and Native Speakers of English as a Function of Reading Skill. Reading and Writing: An Interdisciplinary Journal, 9, 387-406. http://dx.doi.org/10.1023/A:1007994928645

Wagner, R. K., \& Barker, T. A. (1994). The Development of Orthographic Processing Ability. In V. W. Berninger (Ed.), The Varieties of Orthographic Knowledge, 1: Theoretical and Developmental Issues (Vol. 8, pp. 243-276). Dordrecht: Kluwer Academic Publishers. http://dx.doi.org/10.1007/978-94-017-3492-9_8

Wang, M., Cheng, C. X., \& Chen, S. W. (2006). Contribution of Morphological Awareness to Chinese-English Biliteracy Acquisition. Journal of Educational Psychology, 98, 542-553. http://dx.doi.org/10.1037/0022-0663.98.3.542

Wang, M., Ko, I. Y., \& Choi, J. (2009). The Importance of Morphological Awareness in Korean-English Biliteracy Acquisition. Contemporary Educational Psychology, 34, 132-142. http://dx.doi.org/10.1016/j.cedpsych.2008.12.002

Wang, M., Koda, K., \& Perfetti, C. A. (2003). Alphabetic and Non-Alphabetic L1 Effects in English Semantic Processing: A Comparison of Korean and Chinese English L2 learners. Cognition, 87, 129-149. http://dx.doi.org/10.1016/s0010-0277(02)00232-9

Wang, M., Park, Y. J., \& Lee, K. R. (2006). Korean-English Biliteracy Acquisition: Cross Language and Orthography Transfer. Journal of Educational Psychology, 98, 148-158. http://dx.doi.org/10.1037/0022-0663.98.1.148

Zhang, D., \& Koda, K. (2008). Contributions of L1 Reading Sub-Skills to L2 Development in English as a Foreign Language among Reading School-Aged Learners. Indonesian Journal of English Teaching, 4, 1-17.

Ziegler, J. C., \& Goswami, U. (2005). Reading Acquisition, Developmental Dyslexia, and Skilled Reading across Languages: A Psycholinguistic Grain Size Theory. Psychological Bulletin, 131, 3-29. http://dx.doi.org/10.1037/0033-2909.131.1.3 